\title{
Eimeria lepidosirenis n.sp. (Apicomplexa:Eimeriidae) of the South American lungfish Lepidosiren paradoxa (O steichthyes:Dipnoi) from Amazonian Brazil
}

\author{
R Lainson/ ${ }^{+}$, Lucia Ribeiro* \\ Departamento de Parasitologia, Instituto Evandro Chagas, Av. Almirante Barroso 492, 66090-000 Belém, PA, Brasil \\ *Departamento de Farmácia, Centro de Ciências da Saúde, Universidade Federal do Pará, Belém, PA, Brasil
}

The mature oocysts of Eimeria lepidosirenis n.sp. are described in faeces removed from the lower region of the intestine of a single specimen of the South American lungfish Lepidosiren paradoxa, from Belém, state of Pará, Amazonian Brazil. Oocysts with endogenous sporulation: spherical to slightly subspherical, $30.8 \times 30.3 \mu \mathrm{m}(28.1$ $\times 25.9-33.3 \times 31.8$ ), shape-index (ratio length/width) 1.0, $n=25$. Oocyst wall a very thin, single layer approximately $0.74 \mu \mathrm{m}$ thick, smooth, colourless, with no micropyle and rapidly breaking down to release the sporocysts. Oocyst residuum a bulky ovoid to spherical mass of approximately $20.0 \times 15 \mu \mathrm{m}$, composed of fine granules and larger globules and enclosed by a very fine membrane: no polar bodies seen. Sporocysts $15.5 \times 9.0 \mu \mathrm{m}(14.5 \times 8.0$ - 16.0 × 9.0), shape index 1.7 (1.6-1.8), $n=30$, ovoid, with one extremity rather pointed and with a very delicate Stieda body but no sub-Stieda body: sporocyst wall a single extremely thin layer with no valves. Sporocyst residuum a spherical to ovoid mass of approximately $5.0 \times 4.0 \mu \mathrm{m}$, composed of fine granules and small globules and enclosed by a very fine membrane. Sporozoites strongly recurved at their ends and apparently with only a single refractile body. Site of development in the host uncertain: no evidence of endogenous stages was found in fresh scrapings and stained smears of the intestinal epithelium.

Key words: Eimeria lepidosirenis n.sp. - oocysts - Lepidosiren paradoxa - lungfish - Brazil

As far as we are aware, only two protozoan parasites have been described from the South American lungfish, Lepidosiren paradoxa: namely, Haemogregarina lepidosirenis (Adeleina: Haemogregarinidae) in the erythrocytes (Jepps 1927), and Agarella gracilis (Myxosporea: Chloromyxidae) in the testes (Dunkerly 1915). We describe here the mature oocysts of a hitherto undescribed species of Eimeria in faecal material removed from the lower part of the intestine of a single specimen of L. paradoxa.

Lungfishes (Superorder Dipnoi, within the Class Osteichthyes - the bony fishes) are represented by only four living genera. In Australia by the monotypic Neoceratodus forsteri; in Africa by a few species of Protopterus; and in South America by the single species, Lepidosiren paradoxa. All are fresh-water fishes, inhabiting swampy regions that flood in the rainy season and dry up when there is little rainfall. During the latter season, when their habitat may dry up completely, Protopterus and Lepidosiren hibernate within an aestivation chamber situated at the far end of a tube-like burrow excavated in the drying mud, often for as long as six months, before re-emerging when the area is again flooded during the next rainy season.

Financial support: The Wellcome Trust, London (RL) ${ }^{+}$Corresponding author: ralphlainson@iec.pa.gov.br Received 10 March 2006

Accepted 24 April 2006

\section{MATERIALS AND METHODS}

The infected lungfish was one of several caught by baited hook and line in an area known as "Terra Firme" on the outskirts of the city of Belém, state of Pará, north Brazil, and being examined by one of us (LR) during a study on the blood of free-swimming and hibernating $L$. paradoxa.

Immediate microscopical examination of an aqueous suspension of faecal material from the lower part of the intestine revealed fully developed coccidial oocysts containing four sporocysts. Further material was then suspended in $2 \%$ aqueous potassium dichromate $\left(\mathrm{K}_{2} \mathrm{Cr}_{2} \mathrm{O}_{7}\right)$ and maintained in a loosely covered Petri dish, at room temperature, for subsequent study. Scrapings of the epithelium of the intestine were examined in physiological saline, under a coverslip, for evidence of any developmental stages of the parasite, and smears of the same material were fixed in absolute methyl alcohol and stained by Giemsa's method.

Oocysts and sporocysts were measured using $\mathrm{a} \times 100$ neofluar objective, $\times 10$ eyepieces, and an ocular micrometer. Photomicrographs were prepared using a Zeiss "Photomicroscope III" and Kodak TMX 100 film. All measurements are in $\mu \mathrm{m}$ and given as means with the range in parentheses, followed by the shape-index (ratio of length/ width) and the number measured (n).

\section{RESULTS}

\section{Eimeria lepidosirenis n.sp.}

(Figs 1-4)

The oocysts - In unsporulated forms the sporont fills the oocyst completely (Fig. 1). Mature oocysts (Figs 2-4) are spherical to very slightly sub-spherical and average 30.8 
$\times 30.3(28.1 \times 25.9-33.3 \times 31.8)$, shape-index (ratio of length/width) $1.0, \mathrm{n}=25$. The wall is an extremely thin, single layer which is smooth, colourless, approximately 0.74 thick, and with no micropyle. It is very fragile and rapidly breaks down to liberate the sporocysts. The oocyst residuum is a bulky, ovoid to spherical mass of approximately $20.0 \times 15.0$ and composed of a mixture of fine granules and larger globules enclosed in a fine membrane. No polar bodies were seen in the 25 oocysts studied.

The sporocysts - The four sporocysts are ovoid, with one extremity rather pointed and bearing a delicate Stieda body, but no sub-Stieda structure. They average $15.5 \times$ $9.0(14.5 \times 8.0-16.0 \times 9.0$, shape index $1.7(1.6-1.8), \mathrm{n}=30$, and have a delicate, colourless wall of a single layer and with no dehiscence valves. The two sporozoites of each sporocyst are strongly recurved at their ends, and seemingly with only a single refractile body. The sporocyst residuum, of about $5.0 \times 4.0$, is a spherical to ovoid mass of fine granules and small globules contained in a delicate membrane and usually lying between the two sporozoites.

Sporulation - Oocysts are expelled fully sporulated in the faeces.

Site of development - Uncertain. No developmental stages were detected in the intestine and may be in other tissues, such as those of the testes or kidneys.

Host - The lungfish Lepidosiren paradoxa (Osteichthyes: Dipnoi).

Type locality - Terra Firme, outskirts of Belém, Pará, north Brazil.

Type material - Phototypes in the Department of Parasitology, Instituto Evandro Chagas. Due to the rapid disintegration of the oocysts, formalin fixed oocysts are not available.

Pathology - The infected fish showed no signs of disease due to this parasite.

Prevalence - Uncertain. Only two fish were specifically examined for coccidial oocysts and only one was infected.
Etymology - The specific name is formed from the generic name of the host lungfish.

\section{DISCUSSION}

The oocysts of E. lepidosirenis n.sp., exhibit a number of the characteristics which are peculiar to picine coccidia in general, namely their endogenous sporulation and very fragile wall which is without a micropyle and rapidly breaks down to release the sporocysts. Among the named genera possessing four dizoic sporocysts they can readily be separated from the oocysts of Calyptospora, the sporocysts of which are covered by a thin "veil" which is held in place by a number of strange knob-bearing projections of the wall, referred to as "sporopodia". The sporocysts of Goussia spp., have no Stieda body and the wall is composed of two valves which join in a meridional suture and dehisce in order to release the sporozoites. Those of the single species of the genus Crystallospora, C. crystalloids, have a wall which is composed of two valves shaped like hexagonal pyramids: these are joined at their base to give the intact sporocyst the form of a dodecahedron. Sporocysts of Epieimeria spp., in true eels of the genus Anguilla and the conger eel. Conger conger, possess sporocysts which are hexagonal when viewed end-on.

In view of these marked differences, and in particular the fact that E. lepidosirenis n.sp., has sporocysts with a distinct Stieda body, we have no doubt regarding the parasite's generic status. It is hoped that the examination of further specimens of this lungfish will enable us to locate and describe its endogenous stages of development.

It was once thought that all picine coccidia would utilize direct transmission from one fish to another by way of oocysts expelled in the faeces. However, although some fish coccidia, notable species of the genus Goussia, have been shown to be transmitted in this way, experimental attempts to achieve direct transmission of other parasites have failed, leading to the suspicion that perhaps there were intermediate hosts involved in some lifecycles. Landau et al. (1975) increased these suspicions when they showed that sporozoites of an Eimeria spe-

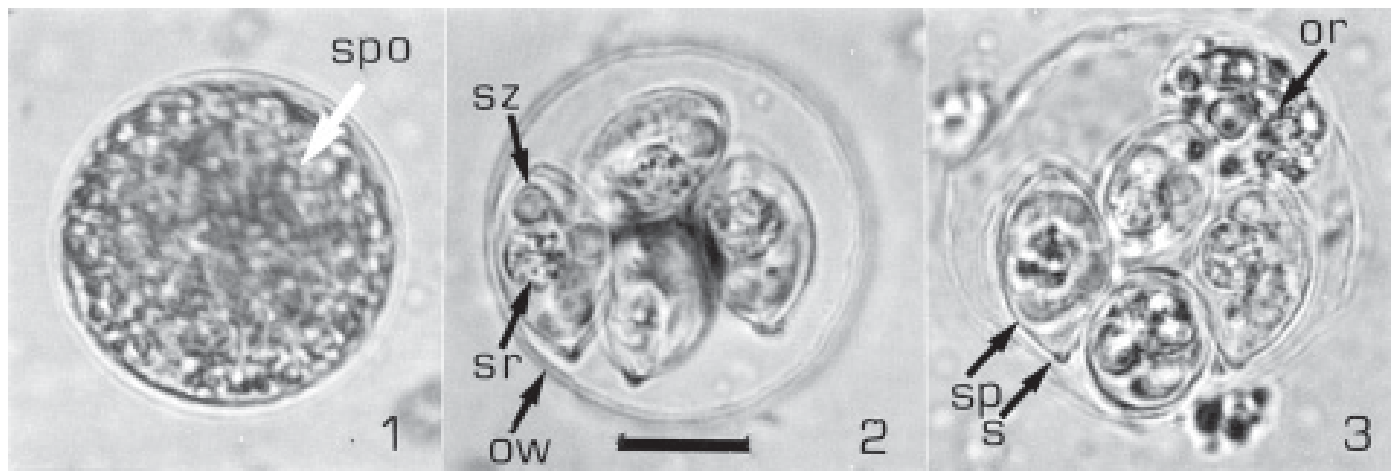

Eimeria lepidosirenis n.sp., of the lungfish, Lepidosiren paradoxa. Fig. 1: an immature oocyst in faecal material removed from the lower part of the intestine. The sporont (spo) entirely fills the oocyst. Figs 2, 3: mature oocysts in the same faecal sample. Note extremely delicate oocyst wall (ow), and bulky oocyst residuum (or). The sporocyst (sp) has a tiny Stieda body (s), and contains two strongly recurved sporozoites (sz) encircling the sporocystic residuum (sr). Bar $=10.0 \mu \mathrm{m}$ for all figures. 


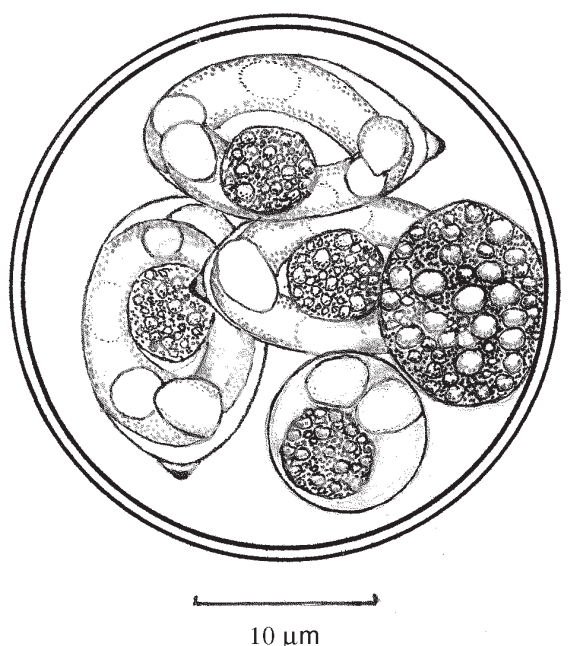

Fig. 4: line drawing of a mature oocyst of Eimeria lepidosirenis n.sp. from the lungfish Lepidosiren paradoxa.

cies of the moray, Gymnothorax moringa, were released in the intestine of pelagic crustaceans of the Order Mysidacea and persisted, in latent form, in the intestinal cells. Final proof of the role of intermediate hosts in the life-cycle of some fish coccidia was furnished by Fournie and Overstreet (1983) and Overstreet et al. (1984), who showed that only the ingestion of crustaceans harbouring such latent sporozoites permitted transmission of the coccidian Calyptospora funduli to another fish. The possibility of intermediate hosts in the transmission of $E$. lepidosirenis clearly needs to be considered.

\section{ACKNOWLEDGEMENTS}

To Constância M Franco and Manoel C de Souza, Instituto Evandro Chagas, for technical assistance.

\section{REFERENCES}

Dunkerly JS 1915. Agarella gracilis, a new genus and species of Myxosporidian, parasitic in Lepidosiren paradoxa. Proc $R$ Soc Edinburgh, Sect A 19: 213-219.

Fournie JW, Overstreet RM 1983. True intermediate hosts for Eimeria funduli (Apicomplexa) from estuarine fishes. $J$ Protozool 30: 672-675.

Jepps MW 1927. Note on a haemogregarine in Lepidosiren paradoxa. Parasitology 19: 285-287.

Landau I, Marteau M, Golvan Y, Chabaud AG, Boulard Y 1975. Hétéroxénie chez les coccidies intestinales de poisons. $C R$ Acad Sci (Paris), Ser D 281: 1721-1723.

Overstreet RM, Hawkins WE, Fournie JW 1984. The coccidian genus Calyptospora n.g. and family Calyptosporidae n.fam. (Apicomplexa) with members infecting primarily fishes. J Protozool 31: 332-339. 